\section{Protests greet new NSF rules on page charges}

\begin{abstract}
Washington. Professional societies have protested to the National Science Foundation (NSF) that a recent change in the foundation's rules, allowing research grants to help cover the costs of publication in commercial journals, will divert money into the pockets of private publishers.
\end{abstract}

The change has been under consideration since last winter, and took effect at the end of September. Scientists receiving NSF grants can now claim the cost of page charges for the publication of their work in all journals; previously they could do so only if the journals were not-for-profit, such as those published by learned societies.

Fred Spilhaus, executive director of the American Geophysical Union (AGU), described the change as "a perversion of the research funding process". The AGU, whose publications get about one-third of their income from page charges, says that the original system was introduced to help keep the subscription rates of learned journals within the reach of ordinary scientists.

The organization is angry that the change will enable money to be paid to high-subscription, commercial journals that circulate only to libraries. "It probably won't hurt us that much", says Spilhaus. "But my concern is a philosophical one: it's wrong for research money to be used in this way." The AGU has called on its 30,000 members to lobby the new NSF director, Neal Lane, to reverse the change.

Bob Hardy, contracts division director at the foundation, says that the decision brings NSF into line with other agencies, such as the National Institutes of Health. "Our basic consideration was that the principal investigator should be allowed to make the decision", he says.

An estimated 0.6 per cent of NSF grants, or about $\$ 20$ million, is allocated each year for the publication of research findings. The decision to include commercial publications was taken in July, before Lane's confirmation. But Hardy says the change in policy was confirmed by the new director.

Not all learned societies are worried about the change. A spokesman for the American Physical Society said that the APS welcomed the "level playing field", and doubted if any commercial publishers would introduce page charges to take advantage of it.

But Gordon and Breach, a commercial publisher with more than a hundred journals in the physical sciences, has announced a scheme under which investigators who pay a voluntary page charge on publication of their work will receive, in return, vouchers of equivalent value for themselves or their library to spend on Gordon and Breach publications.

Colin Macilwain

\title{
Opponents of 'earmarking' claim victory in Congress
}

Washington. Critics of the way in which the US Congress allocates funds to science projects favoured by members of powerful congressional committees are claiming credit for the fact that the amount of money earmarked in such a way has been cut drastically in this year's budget.

Years of sharp growth in 'pork-barrel' funding saw the total money allocated to science projects reach $\$ 760$ million last year, most of it involving the construction of new facilities at universities (see Nature 364, $563 ; 1993$ ). But an early assessment of the budget bills for the current fiscal year, which started on 1 October, suggests that the practice has been sharply curtailed.

George Brown (Democrat, California), who has led a highprofile campaign against earmarking in his role as chairman of the House of Representatives Science and Technology Committee, says that the amount allocated by two key budget committees to such projects has been

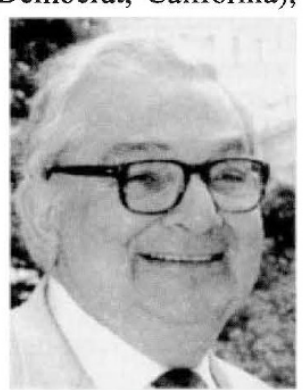

Brown: campaign continues cut by four-fifths.

In principle, the main goal of the campaign against earmarking has been to improve the quality of publicly funded research by ensuring that all projects supported by the government are properly peer reviewed. In practice, however, the issue has also become been part of a wider struggle for power in the House of Representatives between younger members who sit on committees such as Brown's, and the more powerful (if less numerous) members who occupy positions of influence on the appropriations committees, which determine agency budgets.

The balance of power appears to be shifting, at least insofar as the science budget is concerned. Earmarked funds in the energy and water section of the budget, which includes research projects financed through

\section{Schwitters steps down as SSC director}

Washington. Roy Schwitters has resigned as director of the Superconducting Super Collider (SSC) Laboratory, which has been directing the construction of the huge particle physics project cancelled by Congress two weeks ago.

Schwitters has borne the brunt of public criticism of the management of the project. "I' $m$ interested in the science, not in manag- the Department of Energy, have fallen from $\$ 180$ million to $\$ 40$ million. Those in the part of the budget bill covering independent agencies, such as NASA and the National Science Foundation (NSF), fell from $\$ 60$ million to just $\$ 8$ million.

"People in the science community who were looking for a downturn in this [practice] are going to be happy", says Brown. But he admits that the earmarking process is unlikely to disappear entirely, and pledges to continue his fight against it.

The assessment by Brown's staff defined earmarked projects as budget expenditures whose location had been specified in the budget bills, but had not been specifically authorized by Congress, nor requested by the president. Their analysis did not include defence spending, traditionally a big source of earmarked funds, but for which a budget has not yet been finalized.

The staff assessment showed that earmarking in another part of the budget - that covering the Departments of Commerce, Justice and State - has crept up from $\$ 76$ million to $\$ 83$ million. Overall, however, the amount of earmarked science in the four sections studied had been halved from $\$ 410$ million to just under $\$ 200$ million.

Brown's staff stress that their analysis of this year's budget is provisional, and admit that earmarked funds can exist deeply hidden inside the complex budget bills. But they claim that even these provisional results are sufficient to indicate a degree of success for his campaign.

Brown's supporters must now ensure that agencies such as the NSF receive enough money to build properly peer-reviewed research facilities. Recipients of 'pork' often point out that it is the only source of federal funding for new facilities, since agency budgets for this remain tightly restricted.

This year's doubling of the NSF's facilities budget, to $\$ 100$ million, will help to correct this situation (see Nature 365, 467; 1993). But more money will be required next year to compensate for that lost by universities in earmarked funds.

Colin Macilwain

ing the demobilization of the laboratory", he says. "I want to get on with thinking about the future." The former Harvard physics professor says he will continue in his post in order to redirect the science there, until the Universities Research Association, which manages the laboratory for the Department of Energy, appoints a successor.

Colin Macilwain 